\title{
Sustainable Recovery of the Taquari River Riparian Forest: Public Ministry in the Defense of Collective Interests
}

\author{
Andrea Almeida Barros ${ }^{1}$, Luciana Turatti ${ }^{1} \&$ Andre Jasper1 \\ ${ }^{1}$ Universidade do Vale do Taquari - UNIVATES, Brazil \\ Correspondence: Andrea Almeida Barros, Universidade do Vale do Taquari - UNIVATES, Brazil.
}

Received: March 31, 2020

Accepted: April 14, 2020

Available online: April 29, 2020

doi:10.11114/ijsss.v8i3.4798

URL: https://doi.org/10.11114/ijsss.v8i3.4798

\begin{abstract}
Riparian forest, an Area of Permanent Preservation, has suffered anthropic pressure for decades, which makes its recovery imperative. To preserve it, the Constitution has established the responsibility of the Public Prosecutor's Office to ensure diffuse environmental rights. Therefore, under the 1965 Forest Code, the Program for the Sustainable Development of Riparian Forest of Taquari River (PRSMCRT in the Portuguese acronym) was implemented in 14 marginal municipalities, whose areas are part of the Atlantic Forest Biome supported by methodology which was developed for it observing the regional characteristics and coordinated by the Public Ministry of the Rio Grande do Sul State (MPRS). This paper uses a qualitative approach with bibliographic research and analysis of the documents. It is exploratory in its objectives, descriptive about the methodology referred and purposeful in the end, because shows the results of the documentary analysis carried out by the Civil Inquiry that covered the Program and records the methodology developed by UNIVATES for the recovery the riparian area, which served as a basis for combining the required environmental protection, albeit in a smaller area than the legally foreseen in that time, with the constitutional right to property. Results show the recovery of riparian zones after the MPRS and counties work defending the collective rights. The other hand, researches need to be developed in the riparian zone of Taquari river to verify the efficient of the methodology which was created and applied in the PRSMCRT, especially about ecosystem services. Regardless of that, it is possible to replicate the global idea elsewhere.
\end{abstract}

Keywords: recovery of riparian forest, natural heritage, recovery of permanent preservation area - PPA, diffuse rights, public prosecutor's office

\section{Introduction}

With the enactment of the 1988 Federal Constitution (CF/88), Environmental Right was raised to the top of legislation categories. When the Constitution states that "everyone is entitled to an ecologically balanced environment" (BRASIL, 1988), it introduces the fundamental right of the third generation, whose ownership is unclear, and clarifies that it means that environmental heritage is to be protected by both Government and community, in a solidary manner, so as to ensure its availability to current and future generations.

Among other heritages legitimized by Law n ${ }^{\circ} 7.347 / 85$, it established the responsibility of the Public Ministry over this heritage, both in the administrative area and in the judicial area, to restore the ecological role of properties, especially of Permanent Preservation Areas (PPAs), which have been suffering anthropic influence for decades. On the other hand, it is the owner's, holders', or occupant's obligation to protect the environment, as it is a propter rem ${ }^{1}$ obligation.

Both this setting and the need for protecting Taquari River gave rise to the proposal of recovering its riparian zone. However, considering the situation of Taquari Valley (which encompasses 36 municipalities, 15 of which lie on river margins) regarding the size of rural properties, the question then was: how to equate the application of measures for riparian forests, defined by law as PPA, in face of the Forestry Code in effect up to 2012? The previous law (Federal Law 4.771/65) established 100, 150, or $200 \mathrm{~m}$ of PPA according to river width (and Taquari River sometimes has more than $200 \mathrm{~m}$ width and sometimes less), and its application would lead to social and economic issues. Therefore, based on technical criteria, an interim solution was created, which sought minimum protection to the river by recovering its

\footnotetext{
${ }^{1}$ Meaning "attached to the thing." In this case, the fact that the land area is inside a PPA establishes that the riparian forest is to be protected by the land owner.
} 
riparian forest, but also fulfilled the right to property of riverside communities as well as the environmental role of that property.

Vegetation on the margins was classified as Seasonal Deciduous or Semideciduous Forest, which integrates the Atlantic Forest Biome, as it is a remnant of this biome, thus constituting national heritage and being an integral part of the Biosphere Reserve, as per UNESCO, and practically all riverine municipalities have Atlantic Forest fragments in their territories, which are in need of recovery.

The aim of this paper, which has adopted a qualitative approach, with bibliographic research and analysis of the documents, is to scientifically record all the environmental Program for the Sustainable Recovery of the Riparian Forest of the Taquari River (PRSMCRT, in the Portuguese acronym) coordinated by the Public Ministry of Rio Grande do Sul State (MPRS, in the Portuguese acronym) and its methodology wich was developed throughout studies conducted by Universidade do Vale do Taquari - UNIVATES, more specifically, the research conducted by Jasper et al in 2008, who supported that program, and attempted to combine the required environmental protection, albeit within a smaller area than that provided for in law that moment, with the right to property, which is also constitutional, thus adding to the latter the ecological role which is also stated in the Magna Carta like a collective right that it will be protected by the prosecutors.

\section{Method}

Qualitative method will be adopted in this paper for the scientific approach in order to better understand what the riparian forest consists of, what are its functions and the importance of its preservation and recovery, as well as for the characterization of the Taquari Valley, where it flows the river of the same name. Therefore, bibliographic research will be the main source of information at the first moment. In the second, the analysis of the documents comprise Civil Inquiry (CI) $\mathrm{n}^{\circ} 0770.00057 / 2001$ (with more than 800 pages divided in 5 volumes on April, 2020) by the Specialized Prosecutor's Office of Estrela (PJEE), which houses all PRSMCRT records, as well as the records of the Regional Civil Inquiry (RCI) $\mathrm{n}^{\circ} 01342.00002 / 2008$ (with more than 2300 pages divided in 11 volumes on April, 2020), which currently governs it (RIO GRANDE DO SUL, 2008b), by Regional Prosecutor's Office for the Hydrographic Basin of the rivers Taquari and Antas, Rio Grande do Sul. This project was implemented based on the development of its own methodology, which took into account the regional reality, for the recovery of the riparian forest of the aforementioned river and which has been applied since 2008 in the region. The reading of the documents allowed for building a complete document record regarding the Program. It's also exploratory and, about the methodology referred, descriptive research. The procedure is still purposeful, because it's easily replicated.

\subsection{Taquari River Valley}

Taquari River Valley (TRV) is comprised of 36 municipalities and is situated in the central region of RS state; 15 of those municipalities are on the margins of the Taquari River inside the PPA (PORTAL DO VALE DO TAQUARI, 2020). Eminently rural, it has approximately 40 thousand farmers dedicated to agriculture and livestock, generally in an integrated system with the food industry (PORTAL DO VALE DO TAQUARI, 2020; EMATER, 2020; UNIVATES, 2011). It is important to emphasize that TRV integrates the Taquari-Antas River Basin, which encompasses 119 municipalities (RIO GRANDE DO SUL, 2008a) with a vegetation cover of approximately $9,000 \mathrm{~km}^{2}$ of native forests in early, intermediate, and advanced stages of succession (UFSM, 2016).

TRV was colonized by Portuguese families from 1768 onwards, when the construction of Passo do Rio Tebiquary (Tebiquary River Path) was built. At that time, they started clear-cutting riparian forests for the extraction of hardwood and its shipment to Porto Alegre (AHLERT; GEDOZ, 2001). Only around 1845 did the Germans arrive at the region and settle into small riverside colonies. They practiced subsistence farming, agriculture and animal breeding, according to the authors.

Riparian forests, which have important hydrological functions (MANDER; HAYAKAWA; KUUSEMETS, 2005; PRIMO; VAZ, 2006; BREN, 1993; BARRELLA et al, 2000) in controlling margin erosion (FARIA; MARQUES, 1999) and filtering occasional chemical residues, such as fertilizers and agrochemical in production areas (PEREIRA \& PEREIRA, 2010; BARTON; DAVIES, 1993; MANDER; HAYAKAWA; KUUSEMETS, 2005), have been suffering anthropic influence since then, with no care at all for their conservation, as they were always considered an inexhaustible source due to their abundance; this has resulted in their fragmentation (MARTINS, 2007). Conservation efforts in this kind of areas are so important and should consider secondary forest succession as an efficient and viable strategy to increase forest cover and enhance biodiversity conservation (TEIXEIRA et. Al, 2020), especially in the South of Brazil where there are many farmers and land owners can play a key role for successfully increasing forest cover (UNIVATES, 2011). The natural regeneration of the vegetation (secondary succession) can be an effective and low-cost strategy to do this and the associated biodiversity and soil functions (QUIJAS et al, 2019). 
According to the Brazilian Institute of Geography and Statistics (IBGE), this is a Decidual Seasonal Forest, one of the phytoecological regions into which Rio Grande do Sul was divided (IBGE, 2012). This forest, according to article two of Law $\mathrm{n}^{\circ}$ 11.428/2006, is part of the Atlantic Forest Biome (BRASIL, 2006) as long as the native vegetation remnants are in the primary and secondary stages (initial, intermediate, and advanced) of regeneration, as provided for in the single paragraph (BRASIL, 2006). UNESCO, considering the ecological importance of the Atlantic Forest, has established the Atlantic Forest Biosphere Reserve (AFBR) encompassing 35 million hectares in 15 Brazilian states, including RS.

\section{Results Observed until April 2020}

As PRSMCRT was resumed in 2014, some results related to program guidelines ${ }^{2}$ were first observed in the data surveys conducted in the municipalities which had already started complying with what had been agreed, albeit partially, via a contracted team or own team. Over 2,350 riverside properties were supervised, with $25 \%$ of project deployment estimated by mid-2016. Approximately 1,300 TACs were signed at collective hearings (since 2007) conducted in the municipalities or at private hearings, which took place at PJEE. General Câmara is the municipality with the lowest number of conduct adjustments (there are 10), since only 35 properties have been mapped so far.

Approximately 120 thousand trees have already been planted in the Taquari River PPA. Currently, if it's possible, the natural regeneration is the first option, especially because can be more effective and low-cost for the owners of the properties (QUIJAS et al., 2019). Complying with the clauses agreed upon, 253 civil inquiries were filed at CSMP.

Regarding the removal of exotic species provided for in the PRADs, most municipalities inform that either there has been no removal or that it has been partial. In several cases, the technical team reported that the removal of exotic species would cause more damages to the environment. For those cases, DEFAP suggested using the Malpighi ring technique ${ }^{3}$, which has been applied.

Encantado, Muçum, Roca Sales, and Venâncio Aires have not complied with the third clause of the municipal TAC, since they have not placed the indication signs of 'area under restoration'. Regarding Arroio do Meio, there is no such information. The other municipalities have complied with this clause.

Environmental education actions have been performed in Bom Retiro do Sul, Colinas, Cruzeiro do Sul, Estrela, Lajeado, Muçum, Roca Sales, Santa Tereza Taquari, and Venâncio Aires. As for Arroio do Meio, there is no evidence that they have put them into practice, and Encantado and General Câmara have done nothing until 2017, During the last two years, a lot of educational events were developed, like seminars, public hearings and environmental activities with public school students.

Another noticeable result relates to the increase in riparian forest length on the Taquari River margins (as indicated in images extracted from Google Maps shown in Figures 1 and 2). Although they do not refer to the ecosystem issue as a whole, reports by technicians mention the fact that the fauna has returned after PPA restoration, which shows the importance of the project and the need for it to continue.

The work developed by the MPRS and the counties is so important and presents some results that can be showed from Google Earth images. Lajeado, for instance, was $50 \mathrm{~m}$ in 2006 (FIGURE 1); in 2019, after TAC with MPRS in the PRSMCRT, it was as wide as $36 \mathrm{~m}$ (FIGURE 2). It is important to emphasize that this municipality developed the program only downstream of the river, starting at the bridge that connects it to the municipality of Estrela, on BR-386. Regarding vegetation, it is observable that it is quite closed in Figure 2 (2019) compared to Figure 1 (2006), indicating an interesting evolution.

\footnotetext{
${ }^{2}$ The municipality of São Valentim do Sul has not deployed any guidelines, yet, as it signed the TAC in 2012, already under the auspices of Law $\mathrm{n}^{\circ}$ 12.651/2012 as well as Triunfo.

${ }^{3}$ It consists of removing a ring containing some stem tissues or branch tissues from an angiosperm.
} 

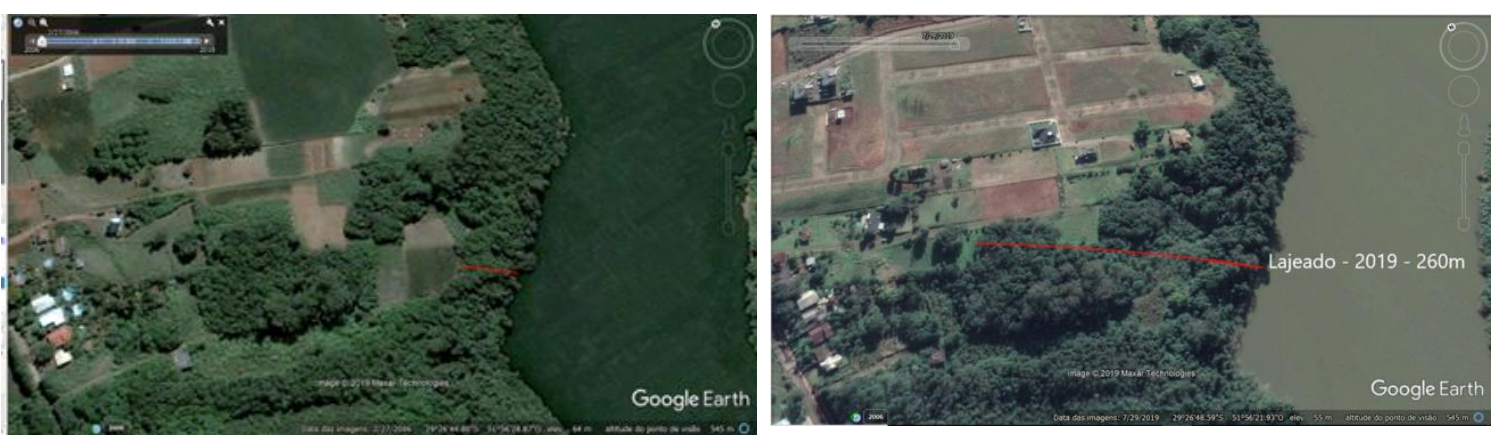

Figures 1 and 2. Riparian forest in Lajeado, 2006 and Riparian forest in Lajeado, 2019

Source: Google Maps (2006) and Google Maps (2019)

Riparian vegetation contributes with the maintenance of ravines in the event of floods as it does not leave either the soil or the slope bare. Furthermore, there is evidence of the formation of a corridor which enables gene flux. Hence, both hydrological and ecological roles are being fulfilled, although minimally (MANDER; Riparian vegetation contributes with the maintenance of ravines in the event of floods as it does not leave either the soil or the slope bare. Furthermore, there is evidence of the formation of a corridor which enables gene flux. Hence, both hydrological and ecological roles are being fulfilled, although minimally (MANDER; HAYAKAWA; KUUSEMETS, 2005; PRIMO \&; VAZ, 2006; BREN, 1993; BARRELA et al, 2000; FARIA \& MARQUES, 1999; PEREIRA, 2010; BARTON \& \& PEREIRA DAVIES, 1993). The natural environment needs to be protected to ensure the long-term health of human populations (COLE \& BICKERSTETH, 2018), the future generations and all of living creatures.

Another important result was the creation and deployment of PRMABHTA, precisely due to the PRSMCRT that has been developed throughout the last decade. This action aims at complying with the MPRS Strategic Planning, remodeled in 2015, but which has maintained the regional scope of actions regarding environmental issues, and the protection of water and restoration of ecological corridors, and consequently, of riparian forest, in the Sustainability axis (RIO GRANDE DO SUL, 2017a), whose objective is to work towards fostering sustainable development to preserve the environment, especially water resources, seeking to balance the prevalence of the economic factor over socio-environmental aspects (RIO GRANDE DO SUL, 2017b, digital text). Its performance shall therefore perpetuate over time until $100 \%$ of river margins are minimally recovered. The PRSMCRT currently covers all the 15 cities bordering the Taquari River. And it's estimated that about $40 \%$ of the riparian zone has already been recovered (RIO GRANDE DO SUL, 2008b).

\section{Discussion}

\subsection{Environmental Constitutionalization}

With the enactment of $\mathrm{CF} / 88$, there was an inversion in the relationship with the environment; up until then, its protection was integrally provided for in the infra-constitutional legislation (BELCHIOR, 2011). Previously, an anthropocentric and privatistic view prevailed, with unlimited exploitation off Nature; afterwards, there was a holistic perspective directed towards transindividual rights and towards their extensive protection. According to Mello (2012), the right to an ecologically balanced environment has become one person's and all people's right.

Several obligations are weighed against this right, and are either bestowed upon the Public Power (because it sometimes appears to play the role of destroyer) or to private powers. In the first case, emphasis must be placed on "preserving and restoring essential ecological processes [...]", described in the first sentence of paragraph one of article 225 of the CF/88. According to Machado (2014), this is one of the means to implement the right to an ecologically balanced environment.

The MP is in charge of the collective right to the environment, as per article 129, paragraph III, of CF/88 (BRASIL, 1988), through a Civil Inquiry ${ }^{4}$. According to Mazzilli (2000, digital text), Civil Inquiry is an investigatory administrative procedure with the objective of collecting elements that might support the proposition of a Term of Adjustment of Conduct (TAC), an extra-judicial action, or a Public Civil Action (PCA), which is a judicial action that

\footnotetext{
${ }^{4}$ Article 26 of the National Organic Law of the Public Ministry replicates the constitutional order, when it states that "in the exercise of its roles, the Public Ministry might: I - launch civil inquiries and other pertinent measures and administrative procedures [...]" (BRASIL, 1993).
} 
aims at defending transindividual interests.

$\mathrm{CF} / 88$ is founded upon the dignity of the human being, which might be understood both in the individual scope (social rights) and in the collective scope, due to solidarity, which is inherent since the subject of this right is undefined or undetermined, according to Leite \& Belchior (2014). And as a principle, dignity is incontrovertible, inalienable (SARLET, 2008), and indefeasible (BENJAMIN, 2001), it aims at social well-being (SARLET, 2008) and is founded on fraternity (BENJAMIN, 2008).

Solidarity between and within generations determines that the obligation to protect environmental quality belongs to the public power and collectivity (GOMES, 2008; LEITE; BELCHIOR, 2014), called shared responsibility by Canotilho (2001). Society is in both ends of the relationship with the environment (LEITE; BELCHIOR, 2014), as it is an active subject because it has the duty to protect it, and it is passive because it has the right to its being ecologically balanced.

And it is on behalf of this solidarity that article 225 implicitly carries the ecological role of society. For this role to be fulfilled, both positive obligations (of preserving and recovering the Permanent Preservation Area - PPA) and negative obligations (the prohibition to destroy it) are the responsibility of whoever is its owner in order to protect a minimum ecological existence (LEITE; BELCHIOR, 2014). This prerogative also appears in the definition of the social role of rural property in article 186 of the constitutional text, where it refers to the adequate use of natural resources available and to the preservation of the environment.

\subsection{The Technical Requirements Applied in the Taquari Valley: A Methodological Proposal}

As a means to recover the hydrological and ecological roles of the riparian forest, the organized civil society sought to recover it, albeit partially, by applying technical criteria especially created for this purpose, in order to adjust what had been judicially set forth to regional reality, as it understood that the enforcement of the federal law in force at the time, the old Forestry Code (Law 4771/65), would have social and economic impacts on the Taquari Valley. From thence was created the PRSMCRT, which is currently coordinated by MPRS, represented by the Chief District Attorney of the Regional Prosecution's Office of Environment of the Taquari-Antas River Basin (PRMABHTA, in the Portuguese acronym). However, its beginning occurred with two different origins and at two different moments, which came together after approximately one year: the hearing at PJEE on August 24, 2001, regarding CI $\mathrm{n}^{\mathrm{o}}$ 00770.00041/1998 , which gave rise to CI.00770.00057/2001 ${ }^{6}$, and in 2002, from discussions held in the scope of the Permanent Forum on Riparian Forests.

In the scope of MPRS, there was the signing of a Term of Cooperation with the then Centro Universitário UNIVATES, through its Foundation (FUVATES), where it set forth the submission of a Project for the Preservation and Recovery of Open Aquatic Ecosystems and its Riparian Systems in the Taquari River Basin/RS. Its aim was to "create and apply methodology for the preservation and recovery of open aquatic ecosystems and their riparian environments in the Taquari River Basin, based on a regional social environmental diagnosis," with the participation of the population involved in the process (RIO GRANDE DO SUL, 2001, p. 39) ${ }^{7}$.

On the other hand, with the objective of intensifying discussions on riparian environments in the Taquari-Antas River Basin, a charter - Carta de Estrela (the Estrela Charter) was edited in the Regional Conference on Riparian Forest, hosted by Estrela on June 25, 2002 (RIO GRANDE DO SUL, 2001). The Permanent Forum on Riparian Forest was put in place with the aim of bringing together regional representative entities, discussing and giving opinions on the topic, and afterwards, reporting them to the authorities, once alternative and feasible forms of restoring riparian environments of the Taquari River were set forth (RIO GRANDE DO SUL, 2001). The diagnosis was developed in the area encompassed between Muçum and Taquari, going through the following municipalities, aside from those already mentioned: Encantado, Roca Sales, Colinas, Arroio do Meio, Lajeado, Estrela, Cruzeiro do Sul, and Bom Retiro do Sul. Its aim was to define recovery and maintenance strategies for the economically active properties, along with getting acquainted with their reality (RIO GRANDE DO SUL, 2001).

According to the aerophotogrammetric survey carried out, the total length of the Taquari River margin is $273.45 \mathrm{~km}$; Roca Sales is the municipality with the longest shore $(51.75 \mathrm{~km})$ and Bom Retiro do Sul with the shortest (12 km) (RIO GRANDE DO SUL, 2001). Based on the Taquari River channel, considering the mean width of the water line, the

\footnotetext{
${ }^{5}$ The object of this CI was the recovery of the riparian forest in Marmitt neighborhood, Estrela, directly impacted by the floods of the Taquari River.

${ }^{6}$ It supervises the recovery of riparian forests in the municipality of Estrela/RS.

7 This project was subdivided in two, which were complementary: i) "Recovery and preservation of riparian environments" and ii) "Limnological, ichthyological, and stocking (repopulation of ichthyofauna) studies on rivers and streams" (RIO GRANDE DO SUL, 2001, p. 40).
} 
Forestry Code in effect at the time required at least $100 \mathrm{~m}$ of PPA on each margin. However, as previously stated, since this is a region characterized by smallholdings and intensive agricultural and livestock activity, compliance with legislation would render most rural properties unfeasible. Thus, it was necessary to meet environmental, social, economic, and legal aspects, somehow protecting the riparian zone, but allowing for the continuation of agrosilvopastoral activities and without halting development in the cities. Each rural property should commit to restoring the minimum limits of the riparian environment, which ranged between 10 to 30 meters, using either agroforestry systems or area insulation. However, this proposal should be submitted to the MPRS, which is the law enforcer and must ensure compliance, as per the terms of article 127 of $\mathrm{CF} / 88^{8}$, which suggested that each entity integrating the Forum should propose basic criteria and subcriteria to be subsequently discussed by a committee formed for this purpose, with representatives of EMATER/RS.

The proposal, based on the conclusions by this committee, defined the minimum number of meters to be recovered considering Taquari River's geometry. Three distinct situations should be considered, according to Tables 1 and 2:

Table 1. Taquari River geometry

\begin{tabular}{ll}
\hline Situation & Margins \\
\hline Situation A & River with straight margins \\
Situation B & River with slightly curved margins (up to $30^{\circ}$ ) \\
Situation C & River with markedly curved margins (larger than $30^{\circ}$ ) \\
\hline
\end{tabular}

Source: Rio Grande do Sul (2001)

These situations should combine four items at the moment when the area to be recovered was analyzed: a) geological composition of the margin; b) margin morphology; c) flood regime; and d) soil occupancy (vegetation). Based on this combination, the level of criticality of the riparian environment would be defined, as follows:

Table 2. River geometry and minimum riparian vegetation measure required

\begin{tabular}{llll}
\hline Criticality degree & \multicolumn{2}{c}{ River geometry and Minimum Meters Required of Riparian Vegetation } & Markedly curved (larger than \\
& In a straight line & Slightly curved (up to & $\mathbf{3 0}^{\circ}$ ) \\
\hline High Criticality & Clay soil & $\mathbf{3 0}^{\circ}$ ) & Clay soil or gravel \\
& Steep slope & Clay soil or gravel & Gradual or steep slope \\
& Risk of floods & Medium to marked risk of & Medium to marked risk of \\
& Bare soil or cyclic crop & floods & Bare soil or underbush \\
& & Bare soil, cyclic crop, or & Basalt \\
Moderate criticality & Gravel & Grderbush & \\
& Gradual slope & Gradual slope & \\
& Medium risk of floods & Low risk of floods & ---- \\
& Underbush & Underbush or pasture & \\
Low criticality & Exposed rock (basalt) & Basalt & \\
& Gradual slope & & \\
& Low risk of floods & & \\
& Underbush or scrubland & & \\
\hline
\end{tabular}

Source: Jasper et al (2008)

Therefore, in situation A, margins were considered as Class 1 (i.e., in a straight line), and criticality should be analyzed to define the minimum length to be recovered. If criticality were considered to be high (clay soil, steep slope, risk of floods, and bare soil or cyclic crop), the area to be recovered should be 30 meters, starting from the river edge. If the soil was comprised of gravel, gradual slope, and the risk of floods were considered moderate and there were scrublands, the area would be classified as having moderate criticality and a 20-meter restoration would be proposed, counting from the river edge. Finally, in case of low criticality, i.e., presence of exposed rocks (basalt), gradual slope, and low risk of floods, with scrubland or bushes, the recovery of 10 meters counting from the river edge would be proposed.

In situation B, where river margins had a curve of up to 30 degrees, criticality would be considered high and therefore, the

\footnotetext{
${ }^{8}$ Art. 127. The Public Ministry is a permanent institution, essential to the judicial role of the State, in charge of the defense of the judicial order, of the democratic regime, and of unavailable social and individual interests. (BRASIL, 1988)
} 
area to be recovered would be 30 meters from the river channel edge, when soil was comprised of clay or gravel, regardless of slope (either steep or gradual), if the risk of floods varied from medium to high, and in case of bare soil with cyclic crop or scrubland. It would be considered moderate criticality when the soil was comprised of gravel, slope was gradual, risk of floods was low, and the vegetation was comprised of scrubland or pasture. In this case, preservation or restoration would be of 20 meters counting from the river edge. Finally, if the soil was basaltic, criticality would be classified as low, and the area to be protected would be 15 meters from the river.

In the third case (C), in which river margins have a curve larger than $30^{\circ}$, with soil comprised of clay or gravel, regardless of slope (either steep or gradual), with moderate-to-high risk of floods, bare soil or scrubland, 30 meters starting from the river edge should be recovered, since this case would be considered as having high criticality. On the other hand, an area with criticality regarded as moderate, the recovery proposed would be of 20 meters, provided soil was basaltic ${ }^{9}$ And in case of doubts regarding the length to be recovered, the most restrictive criterion should always be adopted, tending to maximum criticality, for a higher protection of the river (in dubio pro natura).

According to Jasper et al. (2008), in order to supplement the criteria described above, an analysis of vegetation cover in riparian areas of Taquari River was essential, and it should take place according to Chart 1, which classifies successional stages of the native tree vegetation in the Geopolitical Region of the Taquari Valley:

Table 3. Classification parameters of successional stages of native tree vegetation in the geopolitical region of the Taquari Valley

Primary vegetation is considered to be the most representative local vegetation with high biological diversity, which has not been shallow cut to the point it has not significantly affected its original characteristics of structure and species (no history of cutting, no tree stubs, age of trees > 50 years, epiphytic strata).

Secondary vegetation or vegetation in regeneration were considered those grasslands, shrubs or tree formations derived from natural successional processes, after total or partial suppression of the original vegetation due to anthropogenic actions or natural causes.

\section{I - Initial stage of regeneration:}

เ) Successor vegetation with grassland/shrub physiognomy, with average height of up to 3 (three) meters and Diameter at Chest Height (DCH) smaller than or equal to 8 (eight) centimeters, and it could occasionally show tree-sized individuals scattered in the formation;

1) Epiphytes, if any, are mostly represented by lichens, ferns, and pteridophytes with low diversity;

c) Climbers, if any, are generally herbaceous;

l) Debris, if any, forms a thin layer, poorly decomposed, either continuous or not;

) Biological diversity is variable, with few tree species, and it might have seedlings of species typical of other stages;

f) Absence of understory;

g) floristic composition basically consisting of: Andropogon bicornis; (rabo-de-burro); Pteridium aquilinum (ferns); Rapanea ferruginea (capororoca); Baccharis spp. (vassouras); among other shrub and tree species.

\section{II - Intermediate stage of regeneration: III - Advanced stage of regeneration:}

vegetation that has shrubby/tree a) vegetation with tree physiognomy physiognomy and forest formation with predominating over the other strata, forming a height of up to 8 (eight) meters and closed, uniform canopy with wide diameter, Diameter at Chest Height $(\mathrm{DCH})$ of up to height higher than 8 (eight) meters and mean 15 (fifteen) centimeters;

Tree coverage varying from open to close with occasional occurrence of emerging individuals;

epiphytes occurring in higher numbers of individuals than in the initial stage, and higher in Ombrophilous Forest;

d) Climbers, if any, are generally woody; debris present with variable thickness according to the season of the year and location;

f) low to medium biological diversity;

g) understory present;

floristic composition characterized by the presence of: Rapanea ferruginea (capororoca); Baccharis dracunculifolia, B. articulata and B. discolor (coast silver oak); Inga marginata (ingá-feijão); Bauhinia candicans (camel's foot tree); Trema micrantha (grandiuva);

Mimosascabrella (bracatinga);

Solanum auriculatum (wild tobacco). Diameter at Chest Height (DCH) higher than 15 (fifteen) centimeters;

b) emerging species, occurring in different intensities;

c) higher canopy, horizontally wide, over the shrub and herbaceous strata;

d) epiphytes present with large number of species, high abundance, especially in Ombrophilous forest;

e) climbers are generally woody;

f) abundant debris;

g) high biological diversity;

h) forests in this stage might have a similar physiognomy as the primary vegetation;

i) understory generally less frequent than in

the intermediate stage;

j) floristic composition might be characterized by the presence of:

Cecropia adenopus (embaúba); Hieronyma alchorneoides (licurana); Nectandra leucothyrsus (canela-branca/sweet-wood); Schinus terebinthifolius; (rose pepper); Cupania vernalis; (camboatá-vermelho); Ocotea puberula; (canela-guaicá); Piptocarpha angustifolia; (vassourão-branco); Parapiptadenia rigida; (angico-vermelho); Patagonula

\footnotetext{
${ }^{9}$ In urban zones, the area to be protected with vegetation cover should be the entire space between the river margin and the works installed. However, the limit of 30 meters should be respected.
} 


\begin{tabular}{|c|c|c|}
\hline & $\begin{array}{l}\text { americana; } \\
\text { ealeagnoides; } \\
\text { Enterolobium } \\
\text { (timbaúva). }\end{array}$ & $\begin{array}{r}\text { (guajuvira); Matayba } \\
\text { (camboatá-branco); } \\
\text { contortisiliquum; }\end{array}$ \\
\hline Seasonal Deciduous Forest & \multicolumn{2}{|c|}{ Seasonal Deciduous Forest } \\
\hline Density (ind.ha-1): 12,619 & \multicolumn{2}{|l|}{ Density (ind.ha-1): 832} \\
\hline Basal area (m2): 12.43 & \multicolumn{2}{|l|}{ Basal area $(\mathrm{m} 2): 25.88$} \\
\hline Shannon's Index (?): 1.4 & \multicolumn{2}{|l|}{ Shannon's Index (?): 2.47} \\
\hline Seasonal Semideciduous Forest & \multicolumn{2}{|l|}{ Seasonal Semideciduous Forest } \\
\hline Density (ind.ha-1): 13,320 & \multicolumn{2}{|l|}{ Density (ind.ha-1): 929} \\
\hline Basal area $(\mathrm{m} 2): 16.83$ & \multicolumn{2}{|l|}{ Basal area (m2): 28.28} \\
\hline Shannon's Index (?): 1.74 & \multicolumn{2}{|l|}{ Shannon's Index (?): 2.63} \\
\hline Mixed Ombrophilous Forest & \multicolumn{2}{|l|}{ Mixed Ombrophilous Forest } \\
\hline Density (ind.ha-1): 13,382 & \multicolumn{2}{|l|}{ Density (ind.ha-1): 831} \\
\hline Basal area (m2): 24.7 & \multicolumn{2}{|l|}{ Basal area (m2): 31.79} \\
\hline Shannon's Index (?): 1.79 & \multicolumn{2}{|l|}{ Shannon's Index (?): 2.58} \\
\hline
\end{tabular}

Source: Jasper et al. ([2016])

Regarding the understory, Jasper et al. ([2016]) mentioned that the classification occurs according to its structure:

Dense: Closed, comprised of a large number of individuals per area unit, generally with the presence of lianas and/or canebrakes, whose displacement from the forest team and marking in the sampling unit requires opening complete trails using a scythe.

Medium: Semi-open, comprised of a smaller number of individuals per area unit, sparse occurrence of lianas and/or canebrakes, whose displacement from the forest team and marking in the sampling unit requires opening partial trails using a scythe.

Sparse: Open, comprised of a smaller number of individuals per area unit, sparse occurrence of lianas and/or canebrakes, whose displacement from the forest team and marking in the sampling unit requires opening partial trails using a scythe and removing tree branches and the few individuals that prevent the points to be marked from being viewed.

The project could only be effective with the active participation by the riverside community. For that purpose, a public hearing was assigned by municipality, with the participation of farmers and their families, technicians, their union, and the Public Ministry (RIO GRANDE DO SUL, 2001).

The Permanent Forum on Riparian Forest, which later became Permanent Forum on Native Forests and was linked to the Development Committee of the Taquari Valley (CODEVAT), lasted between 2002 and 2005. Both initiatives - by the MPRS which established the CI.00770.00057/2001, and by Univates and EMATER, which created the Forum were developed simultaneously but independently, until their work was brought together in 2003. From 2006 onwards, under the coordination of the MPRS, the activities were gathered into one single project, called the Ecological Corridor Project, currently PRSMCRT, which encompasses 15 municipalities and is linked to PRMABHTA, as per RCI. 01342.00002/2008.

To implement the idea, the municipalities should conduct supervisions and submit individual recovery projects to be approved by the licensing agency. The next step consisted in these projects being forwarded to the MPRS for the assignment of the collective hearing and offering of TAC to the riverside community, and the municipalities would be in charge of conducting project implementation, its oversight, and reporting to the MPRS on the compliance with provisions of the adjustment, as well as developing environmental education actions. Finally, once the Degraded Area Rehabilitation Plan (PRAD) was completely performed, the CI was filed at the PJEE and sent to the Higher Council of the Public Ministry - CSMP for approval (RIO GRANDE DO SUL, 2008c).

The project structure is pyramid shaped, with RCI $n^{\circ}$ 01342.00002/2008 (RIO GRANDE DO SUL, 2001) on the top. In the medial portion are the 15 Civil Inquiries referring to the municipalities and in the lower portion, the CI's of the riverside communities. This is a proactive action by the MPRS, and on account of that, the environmental criminal issue was not taken into consideration as the highest damage occurred during colonization, in the last century, according to BARROS (2017).

At the end, researches need to be developed in the riparian zone of Taquari river to verify the efficient of the methodology which was created and applied in the PRSMCRT, especially about ecosystem services. Regardless of that, it is possible to replicate the global idea elsewhere. 


\section{Acknowledgements}

This research was supported by Univates, the National Council for Scientific and Technological Development - CNPq and the Public Ministry of the State of Rio Grande do Sul.

\section{References}

Ahlert, L., \& Gedoz, S. T. (2001). Povoamento e Desenvolvimento Econômico na Região do Vale do Taquari, Rio Grande do Sul-1822 a 1939. 2001. Retrieved from http://www.cicvaledotaquari.com.br/portal/wp-content/uploads/hist-eco-vt-texto3-1822-1930.pdf

Barrella, W. et. al. (2000). As relações entre as matas ciliares, os rios e os peixes. In Rodrigue, S. R. R., \& Leitão, F. H. F. (Eds.), Matas Ciliares: conservação e recuperação. São Paulo: EDUSP, 2000. pp. 187-207.

Barros, A. A. (2017). Recuperação de Mata Ciliar: Um olhar entre a sustentabilidade e a legislação ambiental. Rio de Janeiro: Editora Lumen Juris, 2017. pp. 197.

Barton, J. L., \& Davies, P. E. (1993). Buffer strips and streamwater contamination by atrazine and pyrethroids aerially applied to Eucalyptus nitens plantations. Australian Forestry, 56, 201-210. https://doi.org/10.1080/00049158.1993.10674608

Belchior, G. P. N. (2011). Hermenêutica Jurídica Ambiental. São Paulo: Editora Saraiva, 2011. pp. 287.

Benjamin, A. H. O. (2001). regime brasileiro de unidade de conservação. In Revista de Direito Ambiental, V. 21, ano 6, jan.-mar. 2001. Campinas: Revista dos Tribunais, 2001.

. (2008). Constitucionalização do ambiente e ecologização da Constituição brasileira. In Canotilho, J. J. G. e \& Leite, J. R. M. (Org.), Direito Constitucional Ambiental Brasileiro (2nd ed). Revista. São Paulo: Editora Saraiva, 2008. pp. 57-130.

Brasil. Lei $n^{o}$ 4.771, de 15 de setembro de 1965. Código Florestal. Retrieved from http://www.planalto.gov.br/ccivil_03/leis/L4771.htm

Lei no 7.347, de 24 de julho de 1985. Lei da Ação Civil Pública. Disciplina a ação civil pública de responsabilidade por danos causados ao meio-ambiente, ao consumidor, a bens e direitos de valor artístico, estético, histórico, turístico e paisagístico e dá outras providências. Retrieved from http://www.planalto.gov.br/ccivil_03/leis/L7347orig.htm

Constituição (1988). Constituição Federativa do Brasil. Retrieved from http://www.planalto.gov.br/ccivil_03/constituicao/ConstituicaoCompilado.htm

Lei $n^{o}$ 8.625, de 12 de fevereiro de 1993. Lei Orgânica Nacional do Ministério Público. Retrieved from http://www.planalto.gov.br/ccivil_03/leis/L8625.htm

. (2007). Lei $n^{o} 11.428$, de 22 de dezembro de 2006. Dispõe sobre a utilização e proteção da vegetação do Bioma Mata Atlântica e dá outras providências. Retrieved from http://www.planalto.gov.br/ccivil_03/_ato2004-2006/2006/lei/111428.htm

(2012). Lei $n^{o}$ 12.651, de 25 de maio de 2012. Novo Código Florestal. Retrieved from http://www.planalto.gov.br/ccivil_03/_ato2011-2014/2012/lei/112651.htm

Bren, L. J. (1993). Riparian zone, stream, and floodplain issues: a review. Journal of Hydrology, 150. Forestry Section, University of Melbourne, Creswiek, Vic. 3363, Australia, pp. $277-299$. https://doi.org/10.1016/0022-1694(93)90113-N

Canotilho, J. J. G. (2001). Estado constitucional ecológico e democracia sustentada. In Revista do Centro de Estudos de Direito do Ordenamento, do Urbanismo e do Ambiente. v. 2, n. 1, pp. 11-18, fev. 2001. Coimbra, 2001. Retrieved from https://digitalis-dsp.uc.pt/bitstream/10316.2/5732/1/revcedoua8\%20art.\%201\%20JJGC.pdf?ln=pt-pt

Cole, J., \& Bickersteth, S. (2018). What's planetary about health? An analysis of topics covered in The Lancet Planetary Health's first year. The Lancet Planetary Health, 2(I), e283-e.284. https://doi.org/10.1016/S2542-5196(18)30143-8

EMATER-RS. (2020). Empresa de Assistência Técnica e Extensão Rural. Regional Lajeado. Apresentação. EMATER-RS: Lajeado, 2020. Retrieved from http://www.emater.tche.br/site/regionais/lajeado.php\#.VzcQwNIrLIU

Faria, A. P., \& Marques, J. S. O. (1999). desaparecimento de pequenos rios brasileiros. Ciência Hoje, v.25, n.146, p.56-61, São Paulo, 1999. Retrieved from http://eco.ib.usp.br/lepac/paisagem/Artigos/metzger1999a.pdf

Gomes, C. A. O. (2008). Direito ao Ambiente no Brasil: um olhar português. In . Textos Dispersos de Direito do 
Ambiente. I vol. Lisboa: AAFDL, 2008. p. 273-291.

GOOGLE. Google Maps. Mata Ciliar em Lajeado. 2006. Retrieved from https://www.google.com/maps (2009). Mata Ciliar em Lajeado. 2019. Retrieved from https://www.google.com/maps

Instituto Brasileiro de Geografia e Estatística - IBGE. Manual Técnico da Vegetação Brasileira. 2. ed. Rev. e Ampl. Rio de Janeiro: IBGE, 2012. Retrieved from http://biblioteca.ibge.gov.br/visualizacao/livros/liv63011.pdf

Jasper, A. et al. (2008). Desenvolvimento de uma metodologia de recuperação da cobertura vegetal de áreas degradadas. In: VI Simpósio Internacional de Qualidade Ambiental Gestão Ambiental Urbana e Industrial, 2008, Porto Alegre. VI Simpósio Internacional de Qualidade Ambiental Gestão Ambiental Urbana e Industrial - Livro de Resumos. Porto Alegre, 2008.

(2016). Parâmetros de classificação de estágios sucessionais da vegetação arbórea nativa da Região Geopolítica do Vale do Taquari. Lajeado, [2016]. Not published.

Leite, J. R. M. (2014). Belchior. Direito constitucional ambiental brasileiro. In Leite, J.R.M.; Peralta, C. E. (org.). Perspectivas e Desafios para a Proteção da Biodiversidade no Brasil e na Costa Rica. São Paulo: Instituto O Direito por um Planeta Verde, 2014. pp. 10-43.

Machado, P. A. L. (2014). Direito Ambiental Brasileiro (22nd ed.). Revista, ampliada e atualizada. São Paulo: Editora Malheiros, pp. 1344.

Mander, Ü., Hayakawa, Y., \& Kuusemets, V. (2005). Purification processes, ecological functions, planning and design of riparian buffer zones in agricultural watersheds. Ecological Engineering, 24(5), 421-432. https://doi.org/10.1016/j.ecoleng.2005.01.015

Martins, S. V. (2007). Recuperação de Matas Ciliares (2nd ed.). Viçosa: Aprenda Fácil, 2007. pp. 255.

MazzillI, H. N. (2000). Pontos Controvertidos sobre o Inquérito Civil. São Paulo, 2000. Retrieved from http://www.mazzilli.com.br/pages/artigos/pontoscontic.pdf

Mello, M. E. (2012). Restauração Ambiental: do dever jurídico às técnicas reparatórias. Porto Alegre: Livraria do Advogado, 2012. pp. 212.

Pereira, L. A., \& Pereira, M. C. T. (2010). Anais do I Workshop Sobre Recuperação de Áreas Degradadas de Mata Ciliar no Semiárido. Anais. EMBRAPA. Documentos on-line $n^{\circ} 234$, dezembro de 2010. Petrolina-PE: EMBRAPA, 2010. Retrieved from http://www.alice.cnptia.embrapa.br/alice/bitstream/doc/884072/1/Lucio2010.pdf

Portal do Vale do Taquari. (2020). Câmara da Indústria, Comércio e Serviços do Vale do Taquari. O Vale do Taquari. Lajeado, 2020. Retrirved from http://www.cicvaledotaquari.com.br/portal/index.php/cic-vt/o-vale-do-taquari/

Primo, D. C., \& Vaz, L. M. S. (2006). Degradação e perturbação ambiental em matas ciliares: estudo de caso do rio Itapicuru-açu, em ponto Novo e Filadélfia Bahia. Diálogos e Ciência. Ano IV. N.7. jun. 2006. p. 1-11. Retrieved from

http://docplayer.com.br/9342291-Degradacao-e-perturbacao-ambiental-em-matas-ciliares-estudo-de-caso-do-rio-it apicuru-acu-em-ponto-novo-e-filadelfia-bahia.html

Quijas S. et al. (2019). Linking biodiversity, ecosystem services, and beneficiaries of tropical dry forests of Latin America: Review and new perspectives. Ecosystem Services, 36. https://doi.org/10.1016/j.ecoser.2019.100909

Rio Grande do Sul. (1998). Ministério Público do Rio Grande do Sul. Promotoria de Justiça Especializada de Estrela. IC $n^{o}$ 00770.00041/1998. Estrela-RS: MPRS, 1998.

. (2001). Ministério Público do Rio Grande do Sul. Promotoria de Justiça Especializada de Estrela. IC $\mathrm{n}^{\circ}$ 00770.00057/2001. Programa de Recuperação Sustentável da Mata Ciliar do Rio Taquari. Estrela-RS: MPRS, 2001.

(2008c). Ministério Público do Rio Grande do Sul. Legislação institucional. Provimento $n^{\circ} 26 / 2008$. Porto Alegre: MPRS. Retrieved from http://www.mprs.mp.br/legislacao/id3880.htm

(2008a). Ministério Público do Rio Grande do Sul. Programa de Atuação Integrada por Bacias Hidrográficas: Diagnósticos. Bacia Hidrográfica Taquari-Antas - DAT. Porto Alegre: MPRS, Retrieved from http://www.mprs.mp.br/areas/paibh/arquivos/diagonostico_dat_zonas_ciliares_taquari_antas.pdf

(2008b). Ministério Público do Rio Grande do Sul. Rede Ambiental da Bacia Taquari-Antas. IC $\mathrm{n}^{\circ}$ 01342.00002/2008. Projeto de Recuperação Sustentável da Mata Ciliar do Rio Taquari. Estrela-RS: MPRS.

(2017a). Ministério Público do Rio Grande do Sul. Mapa Estratégico do Ministério Público do Rio Grande do 
Sul. Porto Alegre: MPRS, Retrieved from https://www.mprs.mp.br/transparencia/planejamento_estrategico/finalidades_objetivos/mapa_estrategico

. (2017b). Ministério Público do Rio Grande do Sul. Objetivos Estratégicos. Porto Alegre: MPRS, Retrieved from https://www.mprs.mp.br/transparencia/planejamento_estrategico/finalidades_objetivos/objetivos_estrategicos

(2016). Ministério Público do Rio Grande do Sul. Legislação institucional. Provimento nº45/2016. Porto Alegre: MPRS. Retrieved from https://www.mprs.mp.br/legislacao/provimentos/11097/

Sarlet, I. W. (2015). Dignidade da Pessoa Humana e Direitos Fundamentais na Constituição Federal de 1988. 10. ed. Porto Alegre: Livraria do Advogado, 2015. 164 p.

Seminário Regional sobre Mata Ciliar. Carta de Estrela. Estrela/RS, 25 jun. 2002. 2 fl. Not published. Typed.

Teixeira H. et al. (2020). Linking vegetation and soil functions during secondary forest succession in the Atlantic forest. Forest Ecology and Management, 457. https://doi.org/10.1016/j.foreco.2019.117696

UFSM - Universidade Federal de Santa Maria. Relatório Final do Inventário Florestal Contínuo do Rio Grande do Sul. Santa Maria-RS: UFSM/SEMA, 2016. Retrieved from http://coralx.ufsm.br/ifcrs/frame.htm

UNESCO. Reserva da Biosfera da Mata Atlântica. São Paulo: RBMA, 2008. Retrieved from http://www.rbma.org.br/rbma/rbma_1_localizacao.asp

UNIVATES- Universidade do Vale do Taquari. Perfil Socioeconômico do Vale do Taquari. Lajeado: UNIVATES, 2011. Retrieved from https://www.univates.br/media/bdr/Perfil_VT_Setembro_2011.pdf

\section{Copyrights}

Copyright for this article is retained by the author(s), with first publication rights granted to the journal.

This is an open-access article distributed under the terms and conditions of the Creative Commons Attribution license which permits unrestricted use, distribution, and reproduction in any medium, provided the original work is properly cited. 